\title{
THE DEVELOPMENT OF GEO-ECONOMICS: A PATH TOWARDS AN INSTITUTIONAL LIBERALISM APPROACH
}

\author{
Ricardo Vega Perez ${ }^{1}$
}

\section{Introduction}

This paper will examine the development of contributions and discussions made to the field of geo-economics. It will conduct an overview of commonly used definitions, instances and scope of analysis that have defined what geo-economics means as well as its instruments and goals pursued. Geo-economics focuses on how states use material foundations of power and use them as foreign policy to exert power so as to achieve goals such as accumulating wealth or pursuing political ends. Then, it will be proposed that geo-economics could also have a point of connection with institutional liberalism. As defined by Keohane (20I2), institutional liberalism promotes beneficial effects on human security, welfare and liberty as result of a more peaceful, prosperous and freer world. Thus, the mobilisation of economic resources, under a geo-economic focus, could contribute to maintain welfare of a state through responsible cooperation rather than sheer competition and rivalry under a zero-sum paradigm.

Geo-economics, as an extension and replacement of geopolitics, has theoretically been embedded in the paradigm of realism. Realism in International Relations supposes that the international system is an anarchy without a supranational authority that could safeguard the sovereignty and security of the state. The state, therefore, must build up all necessary capabilities to reaffirm its autonomy, safety and economic progress over other states. In order to do so, states will design economic policies and means to assert control and influence over other states' resources and policies. Since the onset of the concept of geo-economics, realism has materialised in several geo-economics works, considering that states will balance against one other

I Professor from the Department of International Relations at Universidad Tecnológica de Mexico (UNITEC) - Campus Ecatepec, Mexico. 
by using economic measures in order to gain from the global economy. Those research articles imply that rivalry and confrontation over wealth are reasons to apply geo-economics instruments against other states.

This paper will propose that geo-economics must not only entail rivalry and confrontation to define states behaviour. As the US leadership and its global powers have eroded, other regional state powers have been designing ways to compete and gain from the process of economic globalisation. Nonetheless, new emerging states does not vie with other states in an attempt to dismantle, nor veer, from globalisation; quite the opposite, all states benefit from the current world institutional arrangement. Therefore, this paper will propose that states could construct new forms of multilateral institutions, trade agreements and other initiatives that could mould economic integration and how nations could benefit from it.

In order to achieve such conclusions, this paper will be organised as follows: the first section will present and tackle the theoretical field of geoeconomics, definitions, debates and scope of analysis, particularly within the tradition of realism ${ }^{2}$. This will give way to discuss the interconnection between institutional liberalism and geo-economics, which could be more suitable to all countries with juxtaposing and coincidental agendas to achieve common concordance in order to preserve the multilateral and institutional world system.

\section{Realism and the Haul of Geo-economics}

There are several definitions of geo-economics, most of them have borne out of the tradition of realism as a group of scholars have perceived geoeconomics as an extension of geopolitics. Since it was introduced by Luttwak (I990), geo-economics has become more relevant in the last decades as a framework of study, aimed at elucidating the use of economic sources of power to set diplomatic agendas in order to exert influence and power overseas ${ }^{3}$. He

2 Some other geo-economics contributions use constructivism and Marxism approaches in order to create new conceptions and objectives of geo-economics. Such works will be briefly mentioned and discussed in this paper in order to favour diversity of thought.

3 It is important to point out that this does not mean that states did not use economic foreign policies to achieve specific goals in the past; on the contrary, economic statecraft already existed. For instance, Luttwak (I990) and Baru (20I2) contemplate mercantilism as a form and predecessor of geo-economics, a period from which states started to use trade with its colonies to accumulate wealth, exploit natural resources and establish controls over international commerce to their own benefit. Although the cold War was an era of ideological confrontation, there were between the US and other states over economic matters (Blackwill and Harris 
argued that the end of the Cold War has derived into a new era in which states are more deterred to use military force to achieve strategic goals vis-à-vis the growing presence of economics in state policy-making. He understands geoeconomics as the fusion of the logic of conflict with the methods of commerce as the most important component of state behaviour (Luttwak I990, I9). Therefore, he theorises that geopolitics is replaced by a new form of conflict embedded by economic means, coined as geo-economics.

He attributes this change of paradigm to the end of West-East hostilities and a renewed US dominance over the process of globalisation. His postulation considers the prevalence of a "laissez faire attitude", which is possible to imply it as a liberal order backed by the US - and other states committed to a freer world. Furthermore, and as part of the current economic globalisation, Luttwak (I990) reckons that states occupy a smaller part of the economic space; and yet, they have economic interests and goals that they would like to realise. Thus, the arena of confrontation is borne out of economic nature, reason why means and ends of state rivalry must belong to the economic domain. To him, a state will have several preoccupations over money matters, the most important of them is if other states could be earning something that is taken away from its own. The zero-sum paradigm is the source of conflict amongst states and their behaviour towards economic activities such as deregulation, industrial policy choices, construction of infrastructure projects and the pursuit of free trade agreements must be strategically thought to compete for economic gains.

Baru (2013) treats the nexus between geopolitics and geo-economics in two different intertwining ways: "the geopolitical consequences of economic phenomena and the economic consequences of trends in geopolitics and sources of national power" (Baru 2013, 37). To him, there is a mutual and reinforcing relation between economic matters and how they are a set of instruments of state strategic policies, which are strongly embedded by geopolitics. With that same thread of thought, Grevi (20II) proposes that geo-economics "encompasses both the conversion of economic assets into political influence and the mobilization of political power to achieve economic objectives". Scholvin and Wigell (20I8) and Kim (20I9) also evaluate that geoeconomics has been defined as an extension of geopolitics because the logic of interstate rivalry and superiority over others is the ultimate end, which emphasizes how competition for relative power drives state behaviour.

Thus, geo-economics and geopolitics are inherently interdependent since its relation "reflect and result from the perceptions, practices, and historical epochs, there was not a particular term used to describe such form of statecraft. 
politics revolving around the nation-state performances in regional and global arenas" (Garrett 20I9, 262). In more specific terms, it can be understood as an extension of the sphere of geopolitics applied to international economic relations, in that sense, geo-economics is an unfolding of geopolitics (Coelho and Pereira 2020). Hence, the logic of geopolitics remains in geo-economics literature and, whilst some authors will ascertain a closer relation between both fields, others will propose a more distant bond between geo-economics and geopolitics, based on means and goals pursued.

Geo-economics, as defined hitherto, is concerned with statecraft so as to achieve desired geopolitical and economic aims. However, "suggesting that a state is marshalling an economic tool in furtherance of some geopolitical objective does not necessarily imply that there are only geopolitical objectives at stake. States design geo-economic policies that simultaneously advance multiple interests-geopolitical, economic, and otherwise". (Blackwill and Harris 20I6b, 27). This means that geo-economics' goals and means are sundry in nature. It also implies that geo-economics is not closely intertwined with political motivations solely. Baracuhy (20I4), for instance, puts more space between geo-economics and geopolitics due to the diffusion of economic power which detaches from prevailing geopolitical conditions. Aside from considering the end of the Cold War as the onset of geo-economics, the author considers that there are other qualitative factors to explain the transit to the logic of geo-economics.

The first of them is the evolving trends in global trade patterns and international commerce negotiations, which display the complexities of a polycentric globalisation and the accelerated revolution in information and communication technologies that reduced costs of communication and coordination. Secondly, by the end of the 2000 s decade, a structural divergence began to emerge between global geo-economics and geopolitics, "subtly decoupling the former from the latter and shaping the power structure of a multipolar globalisation" (Baracuhy 20I4, I2I). Furthermore, geo-economics has emerged as important instrument of study because states are more frequently drawn to flaunt economic power since they have more resources at their disposal. It implies the return of a form of state capitalism: "the concentration of such wealth and large levers of economic influence offers them new sources of foreign policy instruments. States are entering markets directly not just for profit" (Blackwill and Harris 20I6b, 37). Thus, it is plausible to affirm that last decades have witnessed profound changes in how states interact with one another and the sources of power that defined state relations in the global economy.

This has led to several definitions of geo-economics and how it is 
circumscribed on certain contexts and country cases. One import group of literature have focused on states as agents of economic power, broadly understood as the use of statecraft for economic ends (Mattlin and Wigell 20I6). States, therefore, will contemplate geo-economics as an interdisciplinary set of tools that includes geopolitical factors, economic intelligence, strategic analysis and foresight. Its objective is providing a tool for states in order to develop and implement successful strategies to conquer markets and protect strategic segments of the domestic economy, amongst other things (Csurgai 20I8). Any foreign trade, finance, investment, and industrial policy can be considered instruments for geo-economics, as long as they are deliberately designed and implemented to attain economic and political strategic objectives (Kim 20I9, I55). It permeates all areas, from production-technical innovations, specialisation of human resources, technological advances, adequate institutional arrangements and so on.

Geo-economics' main goal is aimed at the accumulation of wealth through market control (Cowen and Smith 2009). Geo-economic means use market-based instruments to assert power and influence. For instance, a country could try to bend the flows of trade, capital and knowhow into its advantage (Holslag 20I5), or, for example, widening exports is a geo-economic strategy as it expands the country's wealth as an attempt to limit economic vulnerability. Moreover, geo-economics strategies are also capable to shape how businessman behave in order to adapt to restrictions and opportunities provided by state economic policy (Calvo 20I8).

This way, the use of economic means promotes and defends national interests so as to produce beneficial geopolitical results (Blackwill and Harris $20 \mathrm{I} 6 \mathrm{~b}, 20$ ). Geo-economics encompasses both the conversion of economic assets into political influence and the mobilization of political power to achieve economic objectives (Coelho and Pereira 2020), and through economic engagement policies, a state can make others become more dependent on it (Kim 2019, I57). Therefore, all economic strategies, whether they are sets of direct state control or instruments to stablish free-market mechanisms and policies, if they are designed to impose one's strategic goals, they can be considered a form of geo-economics. Strategy and political influence are core elements of statecraft when applying geo-economic policies. Besides, as the ultimate goal must be the accumulation of wealth, it eventually increases the state capabilities to apply geo-economic policies as well. In other words, the implementation of successful geo-economic strategies would enhance the state with more geo-economic possibilities to exert more economic power.

Other notions of geo-economics also include security concerns. Cowen and Smith (2009) consider that security "underlines conflicts between the 
logics of territorial states and global economic flows, the proliferation of nonstate and private actors entangled in security, and the recasting of citizenship and social forms, reinforcing a geo-economic reinterpretation on state security" (Cowen and Smith 2009, 25). To them, a territorial expression of power and geopolitical calculation is not extinguished by this rise of geo-economics. Instead of conquering territories, states strive for accumulation of wealth through market control. From that perspective, tensions over security and economic commitments are amplified since economic interdependence does not perfectly coincide with security arrangements any longer (Baracuhy 20I4, I27). Geo-economics does not displace military security concerns; however, economic security has been elevated to the scale of strategic priorities of a country's national interests. Economic security has become a vital component of regional powers' ability to project their power and influence (Wigell 20I6).

Finally, other authors recognise that economics is not a space dominated by the state alone. There is an intricated web of interests amidst private enterprises and the state. International companies have concentrated a lot of economic power and exercise monopolistic and oligopolistic practices to the point that they abuse their growing market power in order to limit and distort competition. This situation has increased companies' abilities to exercise economic power so as to vie for certain territories, markets and natural resources with nation-states. Thence, transnational companies also become a driving geo-economic force, capable to either act independently of any state interference or jointly help states to design economic policy.

Therefore, there are states that have preferred to interfere in certain economic sectors due to political motivations (Santos Neves 20I7). That situation has prompted to private firms and interest groups to be concerned in pursuing their economic interests through state policy. In fact, the private sector contributes to enhance geo-economics capabilities of the state through innovation, technology development and capital formation. Hence, state behaviour could also be driven by interest groups that attempt to direct its actions on the international arena for their own benefit. Businesses need state support since they also are active economic operators (Luttwak I990), driven by the individual rationality of investors and firms seeking to benefit from the world's biggest economic opportunity, and whose cumulative effects are generating major geopolitical consequences (Kapur and Suri 20I4).

Besides, businesses have expanded their operations worldwide and decisions made over trade agreements, location of industrial complexes, trade liberalisation agendas, wage differentials and development of technology impact the profit-maximizing demeanour of private actors. These companies' activities have turned trade and investment linkages into extremely complex 
cross-border networks of productions, and have also transformed financial tools into immediate transfers of capital and loans to fund transnational operations. The collusion of private firms with state economic policy is a key geo-economic trend in the creation of innovative environments through the internationalization of knowledge power, which has resulted in an unbreakable unity between the geo-economics and competitiveness in today's globalised world (Kim 20I9, IO-II). Countries with assured access to natural resources, capital, technology capabilities and qualified human resources have an advantage over those dependent on capital and goods imports for survival (Baru 20I2, 9-10). Furthermore, if a state is capable of consolidating a middle class, combined with governance innovations, such as good fiscal capacities, military capabilities and modern infrastructure, basis of geo-economic power are enhanced (Santos Neves 20I7, 92).

Nonetheless, it is not enough to be efficient, competitive or capable of solving the internal structural problems to succeed in the global economy. States and firms must build up interest connections, institutional linkages and participate in relevant state-private sector coalitions. Economic diplomacy can be seen largely as a strategy to respond to this convoluted situation and the growing integration of economic, political and security dimensions (Santos Neves 20I7, 9I). As a matter of fact, geo-economics is a concern of geopolitical calculus embedded in diplomacy, state security and market mechanisms that responds to the profound changes that have taken place in the last decades, where the international power equilibrium that shaped globalisation has been transformed, with the gradual drifting apart of the alignment between geoeconomics and geopolitics, security arrangements, the cross-border character of businesses and the growing presence of a multipolar dispersion of power and the concentration of economic wealth in certain industries.

The complex lattices of the world economy that overlap and encompass sundry private and state interests turns the balance between geopolitical and geo-economic interests and concerns into a situation that is really difficult to anticipate. Therefore, geo-economics presupposes that state relations orbits around a condition of vulnerability and interdependence. States, capable of implementing geo-economics, try to create or exploit this condition in its relations with other states in order to induce desired strategic outcomes (Luttwak I990, I8, Baracuhy 20I4, I2I). For that reason, sources of geoeconomic power and how they shape a nation's relations with the world must be carefully and strategically designed (Baru 20I3, 39).

Since not all states are equal in their capacity to project geopolitical power, "there are certain structural features — or geo-economic endowmentsthat dictate how effective a country is likely to be in the use of geo-economic 
tools" (Blackwill and Harris 20I6b, 27). The larger the geo-economic capabilities, the more efficient the state is capable to apply geo-economic tools to balance against other states, and profit from it. By accumulating more economic means and expand its possibilities to influence the globalisation process, it can guarantee its security.

Realists, in fact, emphasise the vulnerability and unpredictability characters of the current world order so as to suggest that the state must project power onto other states in order to reduce undesirable outcomes that could be caused by state fragile positions. The use of geo-economics, hence, provides states with instruments to assure a better environment that assure its economic security and political goals whilst asserting its power position in relation to other states. However, realism is not the only paradigm that has contributed to discuss geo-economics. The following section will briefly discuss other contributions in order to extend diversity of thought in this paper.

\section{Other Approaches to Geo-economics}

Constructivism and Marxism approaches have come to consider other theoretical tools to discuss geo-economics. As acknowledged by several scholars, geo-economics is in infant stages of construction, reason why academic contributions are being done to broaden the debate. Constructivists, on the one hand, consider that the logic of conflict, the complexities of globalisation and its multipolarity character affect the perceptions of states. Thus, within a geo-economics scope of analysis, the state is encompassed with a force capable of transfiguring the economic and political international arenas, where the nation-state and the world economy are mutually reinforcing one another. Geo-economics enables states to use new foreign policy tools and choices, transforming the nature of diplomacy (Blackwill and Harris 20I6a, I04).

Luttwak (I990) proposed basically a lineal and consequential change from geopolitics to geo-economics. His work has been critiqued for that assumption and constructivist works have recast this change of paradigm. Cowen and Smith (2009) provide a theorisation in which they consider that geopolitics has been historically deconstructed, a process in which the state was once the central role, but it has been gradually supplanted, particularly since the end of the Cold War. The state occupied the geopolitical social space but its erosion has given rise to the logic of geo-economics. To them, the geopolitical logic is not extinguished, but "significantly circumscribed and 
reworked as they focus on how the new global economic flows recast social forms, providing for an emerging geo-economic social in which territorial security is reframed to accommodate these transnational flows" (Cowen and Smith 2009, 25). It also recasts security in economic terms and reframe the state as a geo-economic agent that seeks to accumulate wealth through market control rather than through acquisition and control of territory.

Therefore, it is surmised that geo-economics is built on a strong belief that economic measures, when employed in place of military force, are capable of altering other states' views, behaviours, or interests in high-stake situations (Kim 20I9, I56). Geo-economics is capable of transforming territorial and economic security spaces by adapting supranational flows into economic terms and reframe the state as a geo-economic agent that seeks to accumulate wealth (Cowen and Smith 2009, 25-26). Thus, all economic measures for geo-economics work by politically distorting economic conditions and manipulating important aspects of international economic exchanges, and inadvertently, constrain free economic transactions of domestic firms and individuals (Kim 2019, I60-163).

Hence, the geo-economic social establishes a relationship between economic policy and changes in the national power and interprets the world through economic indicators, the interconnection of national economies, transnational economic power and their involvement in the global chains of goods and services production (Scekic, Draskovic and Delibasic 20I6). Geo-economics, understood as state intervention, is capable of transforming geographical spaces in times of crisis, change and its political consequences within a geographical space and affect the scope of state sovereignty (Mattlin and Wigell 20I6, Kutz 20I7). In turn, geo-economics has given way to the emergence of a state project in which the summating of institutional and international dimensions of state-building now reflect the prioritisation of economic growth and global competitiveness of the state (Chacko 2015, 329). Geo-economics creates new forms of global and regional engagement that have served to further deepen state transformation. In this sense, geoeconomics presents an innovative role for designing and transforming the world order. (Scekic, Draskovic and Delibasic 20ı6).

Geo-economics, instead of being driven by utter confrontation and a zero-sum rationale, constructivist approaches provide a new conception of the state, which possesses transforming capabilities so as to modify its space, institutions, beliefs and political agendas under an economic approach. Geoeconomics, rather than balancing against other states in order to secure its economic ends, is defined by constructivists as state policies that are capable of transforming the economic space through several instruments, wherein 
the logic of geopolitics is deconstructed by the rationality of economics to reshape state behaviour. Therefore, the state is the most important agent of transformation from geopolitical social practises to geo-economic social forms of state interactions and have served to transform state policies (Chacko 20I5). In other words, state has transformed itself to be capable of building geo-economic competences which are useful for moulding its relations with other states; simultaneously, the global economy affects state behaviour and the way it designs economic policy.

Finally, and aside of the realist and constructivist approaches to define geo-economics, there are explanations that detach from prior definitions and uses. Marxist methods expound geo-economics as a form of discourse, which only attempts to exert the expansion of national interests. Sparke (2007) argues that geo-economics is a discourse that shapes US worldwide security strategies since "it is a tool of capitalism assimilation within a geographic notion of distribution of power and geostrategies that are favourable to the US capital". In this sense, Morrissey (20I7) considers US geo-economics as the military coalesce in the strategic and technological enactment of militaryeconomic securitisation. On the one hand, neoliberalism is secured on a global scale through market liberalisation; but, on the other, the US uses the same devastating use of imperial violence to maintain its global dominance.

Domosh (2013), Tavares and Metri (2020) also consider that geoeconomic imaginations fuelled and legitimized economic expansion since it is a narrative of how geo-economics has refigured the ideology of civilisation, bent to suit the needs of US-based international companies. This way, geoeconomics is an instrument of political legitimacy and construction of a global identity to a national political elite (Giacalone 20I6, I35). This has been building a concept of geo-economics that detaches from the perspective of geographic causality and through the materialist method present in the Marxist approaches and Imperialism Theories. Coelho and Pereira (2020) propose that geo-economics overlaps with World System Theory since geo-economics is a phenomenon of economic strategy, which incorporates research agenda elements such as trade policy, investment policy, economic and financial sanctions, financial and monetary policy, etc. They are all used to achieve the geopolitical objective of capitalism assimilation within a geographic notion. Hence, it is possible to infer that geo-economics is a form of spatiality of imperialism comprising inequalities between core and periphery in the world economy (Coelho y Pereira 2020). 


\section{The Rise of Geo-economics}

Hitherto, it is possible to identify that several definitions of geoeconomics, especially those presented as an extension of the logic of geopolitics, follow the tradition of realism within International Relations. In this situation, states balance against each other as nations are mutually perceived as threats to their own security and interests. This results in the mobilisation of economic resources, diplomacy and other sort of means to achieve economic goals, even if it means that such ends are detrimental to other states.

However, a contradiction arises: does the post-Cold War US hegemony is the cause of geo-economics? If the US were to guarantee the world economy, then it would be possible for its government to impose and preserve its economic power and the geopolitics of US capital over the global economy. Furthermore, if there were a commitment by all states to liberal values of commerce and institutions, the US hegemony would be reinforced, without any type of confrontational demeanour by other states. What happens is the opposite, geo-economics is defined by confrontation and rivalry amongst states in order to get the most from the global economy, even if that means to balance against the US and oppose the institutions, rules and values backed by the US and other Western democracies.

Geo-economics is, therefore, a response to the waning of US relative hegemony. Contrary to what Luttwak (I990) had predicted, geo-economics has come to be a response to US decline in a growing multipolar world system (O'Loughlin and Anselin 1996, Mattlin and Wigell 2016, Troxell 20I8). This has come to spawn a dominant trend in world politics towards regionalisation rather than globalization, and fragmentation of unipolar hegemonic leadership and power into several new emerging powers. This has resulted in the weakening of the liberal economic order due to the emergence of new regional powers that is dividing the world into trade blocs, in which the US-backed globalisation is transiting into a multicentric configuration of the world system.

It is true that the post-war globalisation process was mainly conducted by the US and Europe and the rules promoted by these countries, which hinged on liberal values and institutions that promoted a freer order; nonetheless, the emergence of new regional powers, who might not be fully contented with neither the US-led globalisation - nor the existing rules, are balancing against them, using geo-economics means to achieve so. Even if the US remained as an unchallenged power at the end of the Cold War and its dominance endorsed the continuation of such model of global economic 
integration, the fact is that in a matter of decades, the unipolarity has being fading rapidly, especially since the 2008 financial crisis.

As a matter of fact, the emergence of new world powers has paved the way to important contributions to geo-economics literature, which attempts to identify new state relations and their economic foreign policies that have prompted changes in the global economy. They consider that the concentration of economic power and the intricated regionalization process of conglomerates and transnational companies are shaping state responses to the complexities of the global power system (Baru and Dogra 20I4, Santos Neves 20I7, Troxell 20I8). Moreover, the recurrent economic crisis in the last three decades have put more pressure on the societies that contributed to build and preserve the international liberal order and now, they are being challenged by emerging state powers - China, India, Russia, amongst others. In this multipolarity, diversity becomes the rule (Baracuhy 20I4, I27), which has turned geo-economic responses more heterogeneous, resulting in countries that may not be concerned in preserving the current status quo.

Considering the above-mentioned factors, relevant literature has focused on country cases to evaluate how emerging powers - and well stablished developed economies, are prompted to resort to geo-economic agendas. For instance, China has received a lot of attention for its Belt and Road Initiative (BRI) project ${ }^{4}$ and how the Chinese money has benefited countries from the Central Asian region, using Chinese money to build infrastructure projects, from which China expects to have access to its abundant energy resources and create more channels of international trade to farther economic regions such as Europe and Africa (Kellogg 2003, Yeh 2016, Golley and Ingle 20I8, 55). Furthermore, the BRI project presents an opportunity for the Chinese government to give renminbi-nominated credit and loans to recipients and turn its currency into a more internationalised payment method (Yan 2020). In Asia-Pacific, China-backed Regional Comprehensive Economic Partnership (RCEP) is attempting to create a support base against US proposed Transpacific Partnership (TPP) and create a large free trade area, orbiting around the Chinese economy. Unlike the US and Europe, China does not demand democratic advances in the countries where its money is

\footnotetext{
4 It is an enormous project that paves the way to the Chinese government promote its economics interests to other continents through loans, subsidies and other forms of assistance to attract friends and partners and help them build infrastructure projects, contributing to the expansion of trade in the Eurasian continent and west region of China. Through the BRI initiative, the Chinese government is expanding its presence overseas, simultaneously the Chinese economy is transiting from export-led growth to a local consumption-based economy, it is using huge surplus industrial capacity in infrastructure and heavy machinery sectors to produce goods necessary for the BRI projects (Bhoothalingam 20I6, 48).
} 
invested in. This turns China's geo-economic policies into more flexible and accommodating sources of income for receiving countries, and it is slowly reconfiguring the geopolitical order that has been the dominant global social order since World War II (Forough 2019, 277).

India is another case of a rising power. Since the Indian economy commenced its reforms to open up to FDI and international trade in the eighties, the country has increasingly become more dependent on its international environment. Hence, India decided to secure its future economic development to East Asia, reason why it has pushed several initiatives to secure investment, export markets and natural resources necessary to boost its economic growth. On the hand one, Baru (2013) contemplates that India must gain autonomy and self-reliance in the context of economic interdependence in order to draw economic opportunities. On the other hand, geo-economic discourses have come to India's frontline due to the construction of a state focused on the prioritisation of economic growth and global competitiveness (Chacko 20I5, 329). Additionally, India shares other governments' concern over China's rise and it has strategically cooperated to build a quadrilateral framework involving Japan, the United States and Australia, "described as the alliance of democracies, or as an 'arc of freedom and prosperity', aimed at containing China's rise” (Jain 2010, 409).

The EU, its members and their agendas are under geo-economic interpretations as well. For instance, Germany's handling of the 2009 European economic crisis was conditioned by the rise of China and other emerging powers, which "changes the significance of the eurozone in the global supply chains within a logic of conflict" (Germann 2018, 602). The EU project itself, its expansion and the launch of euro are causing a dollar-reserves decline, giving way to the coexistence of multi-currency reserves and the emergence of geo-economic monetary policies (Sidaway 2005). Additionally, energy is another concern of geo-economic consequences for the EU since its gas and oil supplies commingles with security and diplomatic relations with several states, such as Russia, Turkey, Iran and the Central Asian region; matters, which are being handled under a liberal perspective (Bilgin 20I0). Regional inequality is perceived as another threat to political and social cohesion at the core of the EU, problems that could be solved through a geo-economic perspective to support the periphery via mobilisation of economic and fiscal policies to boost productivity in the manufacturing sector (Fingleton 2004). The competitiveness of the European block will also depend on the Brexit negotiations to have access to the London financial centre (Dorry 20I7).

And finally, the US, which although has been described by Blackwill 
and Harris $(2016 b)^{5}$ and Cruz de Castro (2000) as a reluctant nation to apply geo-economics and form a collective and cohesive approach towards economics as part of a foreign policy agenda, it is important to outline that there are administrations that pushed geo-economic agendas. Certain administration policies have been understood through the lenses of geo-economics such as the Clinton government, which used NAFTA to impose a globalisation model centred on US corporate interests (Saxe-Fernandez I996). Another example is the Obama administration and the launch of TPP as an important building block of its global strategy so as to create a critical mass of countries that support its geo-economic objectives, particularly, the contention of the Chinese influence (Rashish 20I4, Baru and Dogra 20I4). Although China is one of the biggest concerns of the US, the Trump administration's protectionist stand against the global economy might have catastrophic geo-economic results for global prosperity into the future. (Golley and Ingle 2018, 59).

Therefore, it is possible to identify that established economic centres such as the US, Europe and Japan now coexist with new centres of economic power - China, India and Brazil, amongst other emerging economies. In geoeconomic multipolarity, diversity becomes the rule, which in turn, enhances all states to have broader possibilities to project global power and shape the process of economic integration. States, which have augmented their geo-economic capabilities, have more instruments to design an economic foreign policy that effectively alter its relations with other states to its own benefit. Those geo-economic instruments are diverse, either rooted on state intervention or market-oriented policies, but they are following the dogma

5 Blackwill and Harris (20I6a, 20I6b) particularly recognise that epochs during and prior the Cold War were also sprinkled of examples of how states used geo-economics. Both authors tell an account of how the US has been swaying from administrations more eager to use geo-economics as means to project American influence over the world to governments that preferred other tools to exert its power globally. When comparing different and previous US foreign policies under particular administrations, both authors conclude that such ambivalence is related to an amplified preoccupation with political military measures in contexts like the Soviet Union dismantlement or the war against terrorism. Furthermore, they also consider that there is a persistent neoclassical economic thought amongst US policymakers, who believe that markets and economics must be separated from any geopolitical meddling. To them, the US has been ambiguous and inconsistent when it comes to use geo-economics to project power. They end reflecting that the US should recover its traditional geo-economics, pointing out at the fact that many regional and emerging economies are using geo-economics to advance their strategic goals so as to exercise more influence and control over certain territories, resources and international markets. Particularly, they focus on China, which, in their opinion, is the most important reason to discuss world changes in terms of geo-economics since "it is widely understood that China's emergence is to carry some of the most profound geopolitical effects since the United States emerged from World War II as the world's leading power" (Blackwill and Harris 20I6b, 2I). 
of pursuing and increasing its wealth in order to assert its power over other nations.

\section{Geo-economics and Institutional Liberalism}

Geo-economics, as a theoretical proposal, has been nourished by postulations in the fields of realism, constructivism and Marxism. As a result, several frameworks of study have been contrived to explain how states make policy choices and build state capabilities in order to interact with one another. Rivalry is not adequate enough to explain state demeanour since acute competition over economic profits could cause stringent diplomatic policies that would cause the derailment of the multilateral international order and its institutions.

Geo-economics should not construct state policy instruments aimed at increasing tensions and stiffness in a multipolar world that could turn state relations and geographic areas into a constant powder-keg status, waiting for a trigger that could steer the world towards a repetition of divisions and confrontations of the igth and first half of the 2oth centuries. Hence, it is imperative to contribute to a different conception of geo-economics, one identified with the precepts of institutional liberalism.

Institutional liberalism is understood as the dominance of the view that cooperation in world politics can be enhanced through the construction and support of multilateral institutions based on liberal principles (Keohane 20I2). Institutional liberalism bets on a free world that could guarantee a more peaceful and prosperous world. In order to achieve such goals, institutions must be built to protect such freedoms with caution and restrain. Liberal values ${ }^{6}$ provide a rationale for building cooperative institutions that can facilitate better lives for human beings. Therefore, democratic peace, pluralistic security communities, complex interdependence and an open trading system attempt to capture distinctive features of liberal and democratic societies and their relations.

Since the end of World War II, several institutions were put in place in order to supervise and coordinate states' policies towards specific goals.

\footnotetext{
6 The liberal values contemplate open markets, international institutions, cooperative security, democratic community, progressive change, collective problem solving, shared sovereignty and the rule of law (Kundnani 20I7). It incorporates the rule-based order and considers that states behaviour is not simply determined by power; rather, international law constrains the action of states. Openness of the economic order. breaking down of artificial barriers to the flow of goods, services, capital, knowledge, and people across borders. And finally, the protection of human rights, regardless of religious beliefs, nationality, gender, age and so on.
} 
Institutions and accords such as the IMF, the WB and GATT were aimed at promoting free trade, monetary stability and the establishment of cooperation mechanisms to reduce poverty, build infrastructure and increase the welfare of people. Green and Denemark (I999) define the post-war institutionsbuilding phase as execution, which combined high economic growth, the US cementation as hegemonic world leader and a renewed set of security concerns. Thus, institutional building after World War II, and throughout the Cold War, focused on security issues and contention of the soviet bloc by promoting economic prosperity, social welfare, economic stability and several forms of cooperation. Trade, security, financial stability and monetary assistance were areas of reciprocal cooperation that lasted longer after the Soviet Union's dissolution. As pointed by Keohane (20I2), Deudney and Ikenberry (I999), these mechanisms of cooperation were poorly legalised, and cooperation took place on the basis of mutual self-interest and reciprocity.

Green and Denemark (I999) distinguish that the liberal order entered a phase of decline, in which global problems delegitimate the liberal order and puts it under attack. Keohane (20I2) discusses why the erosion of institutional liberalism has been taking place. The liberal values' decline is product of a lack of legalisation that turned the institutionalisation into a robust set of principles, norms and rules embedded in legalism and moralism 7 . To him, both components have spawned a lack of coherence in the international system. Coherent institutions (and array of institutions) must have clear lines of authority linking them. However, an incoherent system of institutions has arisen due to changes in structure of international power and tensions with liberalism. It is manifested, as Keohane prudently remarks, that those difficulties are not properly caused by liberalism; but liberalism has been unable to realise its core values in a fragmented power and pluralist domestic politics (Keohane 20I2, I28).

Moralism, in Keohane's analysis, is necessary as a guide that can help prioritise the promotion of democratic and liberal values overseas; but, on the other hand, moralism could be used to distort reality and mask treacherous motivations. In the case of legalism, he endorses the idea that legalism provides stable grounds to norm a rough order; nonetheless, legalism might be too rigid to adapt to changes in power and unable to help solve urgent political problems. Therefore, institutional liberalism is facing an impasse, in

7 Keohane (2012) defines legalism as "the belief that progress takes place through law" and moralism as "the belief that moral principles provide valuable, if not necessarily sufficient guides to how political actors should behave, and that actions by those in power can properly be judged on the basis of their conformity to general moral principles developed chiefly to govern the actions of individuals" (Keohane 2012, I29, I32). 
which the distribution of economic power has created sundry and juxtaposed interests amidst emerging economies in a complex economic globalisation process. In several cases, the institutions that have interconnected major national powers have weakened, resulting in incoherencies in the international system.

Geo-economics has hatched amidst a growing counter-narrative to the progressive and pacific narrative of Institutional Liberalism. Although some nations may favour policy changes that are conducive to global prosperity and peace, they may be blocked by protectionist barriers, self-righteous savers, or nationalists and other vested interests (Keohane 20I2, I35). Some geoeconomic policies neglect peace and increase tensions amongst states. For instance, Obama's 'Pivot-to-Asia' was conceived to contain the increasing influence of China, but the Chinese government became more belligerent as response to US interference in the Asia-Pacific region. EU's economic bridges to Eastern Europe has stirred violent actions from Russia. China's BRI is being promoted to nations that lack - or have weak - institutional counterweights, and Chinese money could be used politically to strengthen antidemocratic regimes.

Thence, geo-economics has come to be understood as a set of instruments, policies and security interests that are not necessarily aligned to liberal values, especially when applied by nondemocratic states or by any given Head of State, who is willing to pursue certain economic and geopolitical goals by using coercive, discriminatory - and even intimidating measures. Such forms of interactions amidst states would only further undermine the international system. Confrontation would be more acute if states kept a policy based under a zero-sum paradigm so as to design policies that balance against each other. Reasons why, geo-economics must contemplate incorporating principles and values from institutional liberalism.

An interconnection between geo-economics and institutionalliberalism has already been proposed by Wigell (20I6). His work did a categorisation of geo-economic strategies: neo-mercantilism, neo-imperialism, hegemony and liberal-institutionalism. Each of them is a mixture of competition and cooperation, and if goals pursued are geopolitical or purely economic. In his classification, institutional liberalism is defined by a geo-economic conception of economic resources deployment in order to pursue sheer economic objectives, depicted as an "economy-oriented notion of foreign policy idealism" (Wigell 20I6, I45). It is considered a civilian power that accepts the necessity of cooperation with other states in order to pursue national objectives as it favours multilateralism and economic integration.

However, Wigell (20I6) omits that pursuing pure economic objectives 
comes into conflict with the propositions of international liberalism and the concept of geo-economics itself. On the one hand, all definitions of geoeconomics provide an insight to the relationship of economic power relative to political power - and geography. Geo-economics imply state intervention and that interferes with the efficiency principle of liberal economics. In fact, all works on geo-economics literature incorporate state intervention over political objectives and economic matters as its cornerstone. Statecraft is designed to pursue economic and political objectives - even if those seem to be of mere economic nature. Thus, there is no pure economic policies without state intervention in geo-economics theorisations.

On the other hand, liberal institutionalism turns to institutions and law as constraints of power, and simultaneously institutions rest on political power and on how changes in power generate changes in institutions. As a matter of fact, institutional liberalism recognizes the dependence of economics on politics and does not believe in a harmony of interests (Keohane 20I2). Hence, Wigell's categorisation of liberal institutionalist strategies as purely economic goals contradicts definitions of both, geoeconomics and institutional liberalism. (Wigell 20I6) supposes an idealism over geo-economics in its categorisation of liberal institutionalism but omits the conception of power that lies within the concept of geo-economics itself. Furthermore, he overlooks the fact that institutional liberalism is a response to the relationship between state interactions and political power to shape institutions.

Therefore, a relationship between geo-economics and institutional liberalism must incorporate power relations within institutions and economic policies. The proposition of geo-economics of this current paper is to think of geo-economic goals and its instruments within institutional constraints and a common basis of values, considering that the current globalisation process has sewed several interwoven strands of economic interdependence. Despite several states may challenge western liberalism, the fact is that none of them has attempted to obliterate the current international system; on the contrary, all states benefit from it, whether they are more or less committed to liberal values.

The Chinese government, when picked by the Trump administration to be hit with a rise on trade tariffs, pledged the US to protect free trade and avoid protectionist measures. Whereas several democratic provisions are not granted in Russia, economic freedoms are given as long as they contribute to get the nation rich and, of course, if business interests do not challenge the Russian government. India has continued its economic reforms to liberalise more sectors of its economy to attend to its rusty infrastructure and growing 
demand of investment and employment.

Hence, and despite Russia, China, and other regional powers that have built an anti-liberalism rhetoric, the fact is that all of them depend on the current set of rules, and they all have interest in keeping an economic global system based on liberal values. They depend on democratic peace, pluralistic security communities, complex interdependence and free international trade to prosper. Such characteristics capture distinctive features of liberal, capitalist, and democratic modern societies and therefore, mould state relations (Deudney and Ikenberry I999). States cannot practice isolation strategies since they need to maintain relations with other states to push their economic and political goals, and by rehearsing co-biding into institutions states mutually constrain one another. Institutionalisation of states relations and world politics are capable to exert a significant effect on statecraft (Orozco 2006, I70).

Thus, institutional liberalism is a mechanism to prevent states decide to balance against other states since "establishing institutions of mutual constraint and co-binding reduces the risks and uncertainties associated with anarchy. It is a practice that aims to tie potential threatening states down into predictable and restrained patterns of behaviour, and it makes unnecessary balancing against such potential threats" (Deudney and Ikenberry I999, I82I83). Furthermore, and contrary to balancing strategies, co-biding through institutions provides distinctive features such as transparency, the diffusion of power into many hands, and the multiple points of access to policy-making (Deudney and Ikenberry I999, I87). This, in turn, makes state relations more predictable and harmonised.

Besides, the multipolarity and interdependence of the current globalisation provokes overlooked consequences of farther reach as result of states' actions and omissions when designing economy policy (Solana 20I5). Balancing against other states could not only damage the targeted nation, but it could also harm one's security and one's national business interests beyond suppositions because of the vibrant economic globalisation, which involves a large number of autonomous companies, international banks, running thousands of business decisions and financial transactions every single minute. Under such conditions, it is very difficult to anticipate the distribution of gains and losses.

Therefore, responsibility must be part of any geo-economic agenda. As Solana (20I5) correctly points out, any noxious tactical demeanour ought to be abandoned; instead, a discernment that strategically encompasses security and responsibility must be put in place since the world is more complex, volatile and interdependent. Geo-economics, in this context, should be obliged 
to create new frames of reference and analysis because interdependency constrains state behaviour and sets limits to policy-decisions making. Geoeconomics, rather than becoming a policy of exclusion, intimidation or institutional obliteration, must incorporate economic measures aimed at trying to convince other states that it is in their own interest to take a certain set of actions and respect the rules of the game (Kim 2019, 156).

All states, in this fashion, are aware of the interdependence character of the international economy and politics, and as predicted by most geoeconomics literature, there is no incentives for states to push its economic, security and political interests through military force. Reason why, geoeconomics inherently considers that strategic autonomy in an interdependent world is secured through creating mutually beneficial relationships of interdependence, not from mere assertion of one's independence or nonalignment (Baru 2013, 37). Countries, that are not cooperative in the geoeconomic atlas of the world, are not aware of their economic interests and does not protect them (Scekic, Draskovic and Delibasic 2016, 69).

If geo-economics continued to be only a set of strategies and tactics, under a zero-sum paradigm, the world order could be undermined, resulting in bloc coalitions and higher levels of unpredictability, which would only amplify the risk of bolder confrontations. Insecurity, instability, fragmentation, exclusion, political and economic polarizations would become more acute at national and international levels (Saxe-Fernandez I996, Baracuhy 2014). All the more, coercive geo-economic behaviours spawn an inability to achieve more preferable geo-economic alternatives (Green and Denemark I999, Blackwill and Harris 20I6b). In other words, geo-economics when used in detriment of other states, those affected states would pursue the same policy, leaving other options out and turning the world into a stiffer place to pursue common concordance.

Geo-economics must not become an instrument of fragmentation due to geopolitical motivations since economics, unlike in war, everyone can win and enjoy the fruit of economic growth and development. So, states must responsibly materialise the benefits of interdependence while managing the costs it imposes (Baru 20I3, 37). States need to be aware that several factors, including domestic politics of other nations and the level of their economic and institutional interconnections affect economic policy choices (Friedberg I994). Therefore, autonomy and self-reliance to pursue geo-economic objectives have to be defined in the context of the economic interdependence of nations, which could be only strengthened within multilateral institutions.

The multipolar world could be a hard wold to go through and conflict could be inevitable, but only within effective and inclusive multilateral 
institutions, dissent could be properly managed (Solana 2015, 28). Institutional liberalism could build boundaries to geo-economic strategies since institutions contribute to alloy strategic thinking with security. Security and economic tensions reinforce one another within states interaction (Blackwill and Harris $20 \mathrm{O} 6 \mathrm{~b})$, but the incompatibility of interests found in realist propositions of geo-economics could be solved by an institutional liberalism approach. Since institutions building has formed interactions that contributes to the viability of the international system, institutional cooperation creates mechanisms of reciprocity and common security.

Although institutional liberalism does not promise a continuous and stable concordance, it is a source of hope for improvement, which is tied to institutional checks against retrogression (Keohane 2012, I36). It might also suffer limitations to change due to rigidities and slowness to adapt to international power changes, but geo-economics provides flexible grounds to states since they may enjoy sufficient autonomy to design economic diplomacy, which must be contained by a common understanding of rules and principles. "All nations, aspiring to exercise some sort of hegemony, will need to engage in a 'give-and-take', even involving some 'self-sacrifice', in order to make its hegemony 'tolerable to the other members of the world community" (Keohane 20I2, I3I). In other words, and discussed previously, the complexities of the global economy impede states to have accurate estimations on gains and losses, but it is clear that responsibility and prudence may require a cost in order to promote common security to all states, which in the long run purveys more economic benefits.

Thus, it is important to point out that institutional liberalism is a dynamic commitment to allow countries to be different within a multilateral framework. It is a compromise between the needs for universality on which a strong order must rest on, and the needs for particularity that are inevitable in a plural world order (Wolfe and Mendelsohn 2004). It enhances coalition-building possibilities to all countries since their preferred policies serve interests that go beyond the national interests of world powers (Green and Denemark 1999). Under such conditions, geo-economics, instead of contributing to uncertainty, it could help to reach new forms of adaptation to a world of multipolar distribution of power, providing states a multidisciplinary approach that encompasses several types of economic policy choices, from direct state intervention or market-based strategies in order to create a flexible diplomacy. Those policy choices, however, need to rest on institutional constraints so that multilateral accords and institutions as well as its norms and values could be preserved. This way, the depth of institutionalisation could exert a significant effect on state behaviour, contributing to a more 
predictable demeanour amongst states (Orozco 2006, I70). In turn, state conduct would be more predictable and assertive.

Despite the threat that multipolarity poses to multilateralism, free trade and market-based policies can spread and strengthen liberal democracy. Besides, institutional liberalism permits several states to participate in policymaking since they have a variety of channels and mechanisms for registering their interests with world's great powers (Deudney and Ikenberry I999, I87). Therefore, the expansion of economic interests and interdependence works as an instrument to alter and maintain the preferences and features of other states that are politically and strategically congenial, producing a more strategically and politically hospitable system (Deudney and Ikenberry I999, I9I-I92). Even if rivalry prevailed as a relevant component of geo-economics, as its policies would be institutionally constrained, competition for investing, trade and markets to developing countries would be beneficial in terms of global economic growth.

\section{Final Remarks}

Geo-economics is still a concept under construction, so contributions have broadened the discussions about its scope, instruments, criterions and how states are using it to construct diplomacy and economic policy. As extension of geopolitics, geo-economics offers a framework of study to explain state behaviour based on rivalry, pursuit of economic gains and geopolitical objectives, supported by the logic of realism. However, geo-economics should not rest on tighter competitive strategies that would only undermine the international system. Stiffness and rigidities caused by exclusionary and predatory economic practices would get cooperation and concordance more arduous to achieve.

Hence, strategic cooperation and responsible statecraft must be part of geo-economics, constrained by institutional limits. Multilateral institutions contribute to the international order and restrict any bold form of statecraft that could further destabilise it. Since geo-economics contemplates the lack of compatibility between security and economic objectives as motivations to balance against other states to reaffirm one's economic and political goals, institutional liberalism proposes an alternative to balancing and zero-sum paradigms. Multilateral cooperation, institutions and its values are bridges to reach consent amongst all states to give them a certain level of tolerable security. Absence of conflict is not guaranteed, but if responsibly managed, bolder confrontation could be avoided. 
Geo-economics, as it has been becoming a more recurrent discipline to explain economic policy and diplomacy, it requires a different approach that could incorporate responsibility, caution and restrain. All societies face demanding challenges on poverty, environmental problems, growing inequality, etc., which could be more adequately solved through a multilateral approach. Utter confrontation would not be able to reach a proposal that could contribute to long-term solutions. Therefore, a multipolar world requires prudence and responsibility which could be channelled through a set of agreed of institutions and common values.

Although institutionalists agree that institutions once in place will be hard to dismantle and have persisted over decades, they have been slow to adapt to changes in world distribution of power. If emerging powers are not included in redesigning these institutions, they will likely continue its balancing strategies since they are motivated to resist what they consider imposed institutions (Keohane 20I2). Geo-economics, in this sense, could provide flexibility for states to design independent economic policy that could help states reach new agreements to recreate the international system, capable of tackling the urgent problems that our societies will face in the following decades.

\section{REFERENCES}

Baracuhy, Braz. 20I4. "The evolving geo-economics of world trade". Adelphi Papers 54 (450): I2I-I38.

Baru, Sanjaya. 20I2. "Geo-economics and Strategy". Survival 54 (3): 47-58.

Baru, Sanjaya. 2013. "India and the World: A Geoeconomics Perspective". Economic and Political Weekly 48 (6): 37-4I.

Baru, Sanjaya, and Suvi Dogra. 20I4. "Economic shocks and the geoeconomics of world trade". Adelphi Papers 54 (450): I39-I48.

Bhoothalingam, Ravi. 2or6. "The Silk Road as a Global Brand". China Report 52 (I): 45-52.

Bilgin, Mert. 2010. "Geo-economics of European Gas Security: Trade, Geography, and International Politics”. Insight Turkey I2 (4): I85-209.

Blackwill, Robert D., and Jennifer M. Harris. 20ı6a. "The Lost Art of Economic Statecraft: Restoring an American Tradition”. Foreign Affairs 95 (2): 99-IIO.

Blackwill, Robert D., and Jennifer M. Harris. 20I6b. War by Other Means: Geoeconomics and Statecraft. Cambridge: Harvard University Press. 
Calvo, Ángel. 20I8. “¿Geoeconomía frente a crecimiento económico? El control de las exportaciones de tecnología avanzada en la guerra fría: una aportación desde un país semiperiférico (España)". Revista Bibliográfica de Geografía y Ciencias Sociales 23 (I230): I-36.

Chacko, Priya. 20I5. "The New Geo-Economics of a "Rising" India: State Transformation and the Recasting of Foreign Policy". Journal of Contemporary Asia 45 (2): 326-344.

Coelho, Bruna, and Pedro Pereira. 2020. "Geoeconomics in the light of International Political Economy: a theoretical discussion". Brazilian Journal of Political Economy 40 (I): 22-36.

Cowen, Deborah, and Neil Smith. 2009. "After Geopolitics? From the Geopolitical Social to Geoeconomics". Antipode 4I (I): 22-48.

Cruz de Castro, Renato. 2000. "Whither Geoeconomics? Bureaucratic Inertia in U.S. Post-Cold War Foreign Policy toward East Asia". Asian Affairs: An American Review 26 (4): 20I-22I.

Csurgai, Gyula. 2018. "The Increasing Importance of Geoeconomics in Power Rivalries in the Twenty-First Century". Geopolitics 23 (I): 38-46.

Deudney, Daniel, and John Ikenberry. I999. "The Nature and Sources of Liberal International Order" Review of International Studies 25 (2): I79I96.

Domosh, Mona. 2013. "Geoeconomic Imaginations and Economic Geography in the Early Twentieth Century". Annals of the Association of American Geographers I03 (4): 944-966.

Dorry, Sabine. 20I7. "The geo-politics of Brexit, the euro and the City of London". Geoforum 85: I-4.

Fingleton, Bernard. 2004. "Some alternative geo-economics for Europe's regions”. Journal of Economic Geography 4 (4): 389-420.

Forough, Mohammadbagher. 20I9. "Intervention with Chinese characteristics: The Belt and Road Initiative reconfiguring (Afro-)Eurasian geoeconomics". Conflict, Security \& Development i9 (3): 275-28I.

Friedberg, Aaron L. I994. "Ripe for Rivalry: Prospects for Peace in a Multipolar Asia". International Security I8 (3): 5-33.

Garrett, Crister S. 20I9. "Constructing narratives of global order: The Obama presidency, TPP, TTIP, and the contested politics of geoeconomics". Atlantic Studies I6 (2): 26I-28I.

Germann, Julian. 20I8. "Beyond 'geo-economics': Advanced unevenness and the anatomy of German austerity". European Journal of International Relations 24 (3): 590-6I3. 
Giacalone, Rita. 2016. Geopolítica y geoeconomía en el proceso globalizador. Bogota: Ediciones Universidad Cooperativa de Colombia.

Golley, Jane, and Adam Ingle. 2or8. "The Belt and Road Initiative: how to win friends and influence people". In Golley, Jane and Jaivin, Linda (ed.). Prosperity, 44-59. Canberra: ANU Press.

Green, Daniel M., and Robert A. Denemark. I999. "Cycles of Liberalism in the Twentieth Century”. Humboldt Journal of Social Relations 25 (I): 3I-64.

Grevi, Giovanni. 20II. "Geo-Economics and Global Governance". In Youngs, Richard (ed.). Challenges for European Foreign Policy in 2012: What Kind of Geo-Economic Europe?, 27-36. Madrid: Fride.

Holslag, Jonathan. 2015. "Geoeconomics in a globalized world: the case of China's export policy”. Asia Europe Journal I4 (2): I73-I84.

Jain, Purnendra. 2010. "Japan-India Relations: Peaks and Troughs". The Round Table 99 (409): 403-4I2.

Kapur, Devesh, and Manik Suri. 20I4. "Geoeconomics Versus Geopolitics: Implications for Asia”. In Kaur, Inderjit N. and Singh, Nirvikar (ed.). The Oxford Handbook of the Economics of the Pacific Rim, 290-313. Oxford: Oxford University Press.

Kellogg, Paul. 2003. "The geo-economics of the new Great Game". Contemporary Politics 9 (I): 75-82.

Keohane, Robert O. 20I2. "Twenty Years of Institutional Liberalism". International Relations 26 (2): 125-138.

Kim, Dong Jung. 2019. "The Perils of Geoeconomics". The Washington Quarterly 42 (I): I53-I70.

Kundnani, Hans. 20I7. "What is the Liberal International Order?". German Marshall Fund of the United States (I7): I-IO.

Kutz, William. 20I7. "Municipalizing geo-economic statecraft: Crisis and transition in Europe". Environment and Planning A 49 (6): 1224-1246.

Luttwak, Edward. 1990. "From Geopolitics to Geo-Economics: Logic of Conflict, Grammar of Commerce". The National Interest (20): 17-23.

Mattlin, Mikael, and Mikael Wigell. 20r6. "Geoeconomics in the context of restive regional powers". Asia Europe Journal I4 (2): I25-I34.

Morrissey, John. 20I7. "Geoeconomics in the Long War". Antipode (49): 94II3.

Santos Neves, Miguel. 20I7. "Economic Diplomacy, Geo-economics and the External Strategy of Portugal”. Observare 8 (I): 88-II8. 
O'Loughlin, John, and Luc Anselin. I996. "Geo-Economic Competition and Trade Bloc Formation: United States, German, and Japanese Exports, I968-I992". Economic Geography 72 (2): I3I-I60.

Orozco, Gabriel. 2006. "El concepto de la seguridad en la Teoría de las Relaciones Internacionales”. CIDOB d'Afers Internacionals (72): I6II80.

Rashish, Peter S. 2014. “Connecting Commerce, Geoeconomics, and Security”. In Rashish, Peter S. (ed.). Bridging the Pacific: The Americas' New Economic Frontier?, 5-Io. Washington DC: Atlantic Council.

Saxe-Fernandez, John. I996. "NAFTA: The Intersection of the Geopolitics and Geoeconomics of Capital”. Social Justice 23 (I/2): 63-64.

Scekic, Radenko, Mimo Draskovic, and Milica Delibasic. 20I6. "Neoliberalism in geoeconomics: the case of Southeast Europe". Journal of International Studies 9 (I): 66-75.

Scholvin, Sören, and Mikael Wigell. 20I8. "Power politics by economic means: Geoeconomics as an analytical approach and foreign policy practice". Comparative Strategy 37 (I): 73-84.

Sidaway, James D. 2005. "Asia-Europe-United States: The Geoeconomics of Uncertainty”. Area 37 (4): 373-377.

Solana, Javier. 2015. "Más interdependientes, más responsables". Política Exterior 29 (163): 26-3I.

Sparke, Matthew. 2007. "Forum: Geopolitical Fears, Geoeconomic Hopes, and the Responsibilities of Geography". Annals of the Association of American Geographers 97 (2): 338-349.

Tavares, Maria da Conceicao, and Mauricio Metri. 2020. "A geoeconomia do império e as mutações do capital: os dois ciclos de expansão econômica dos Estados Unidos no final do século XX". Revista de Economia Política 40 (I): 3-2I.

Troxell, John F. 2018. "Geoeconomics". Military Review 98 (I): 4-I9.

Wigell, Mikael. 20I6. “Conceptualizing 'regional powers' geoeconomic strategies: neo-imperialism, neo-mercantilism, hegemony, and liberal institutionalism". Asia Europe Journal (14): 135-I5I.

Wolfe, Robert, and Matthew Mendelsohn. 2004. "Embedded Liberalism in the Global Era: Would Citizens Support a New Grand Compromise?". International Journal 59 (2): 26I-280.

Yan, Liang. 2020. RMB "Internationalization and Financing Belt-Road Initiative: An MMT Perspective”. The Chinese economy 53 (4): 3I7-328.

Yeh, Emily T. 20I6. "Introduction: The geoeconomics and geopolitics of 
Chinese development and investment in Asia”. Eurasian Geography and Economics 57 (3): 275-285.

\section{ABSTRACT}

Geo-economics mostly fall into the realist paradigm of International Relations since it is understood as the use of economic means under strategic military logic as principal instruments of statecraft. However, geo-economics is neither caused by states alone nor driven by multipolar rivalry solely. Instead, geo-economics requires a framework of study which considers that there are countless links of interdependence in the global economy that must be taken into consideration to explain state behaviour. Institutional liberalism provides geo-economics theoretical grounds to maintain cooperation and responsibility as central components of geo-economics.

\section{KEYWORDS}

Institutional Liberalism; Geo-economics; Multipolarity.

Received on August 12, 2020 Approved on April 06, 2021 